\title{
THE TRAINING'S A-COMIN' \\ IN: AN ANALYSIS OF \\ TRAINING DECISIONS USING MICRODATA $^{1}$
}

\author{
Geoff Mason*, Penny Mok ${ }^{\dagger}$, Peter \\ Nunns ${ }^{\ddagger}$, Philip Stevens ${ }^{\dagger}$ and Jason \\ Timmins $^{\S}$ \\ * National Institute of Economic and Social \\ Research, London \\ $\uparrow$ Ministry of Economic Development \\ $\ddagger$ Formerly of Ministry of Economic \\ Development \\ $\S$ Department of Labour
} \begin{abstract}
competitive environment and the occupational breakdown of its staff.
\section{Introduction}

Developing policies to ensure firms have the skills they need is critically important if New Zealand is to raise productivity in industry, improve its international competitiveness and participate more fully in the Knowledge Economy. There is a long literature relating human capital and firm performance. At the microeconomic level, studies such as Abowd, Kramarz and Margolis (1999), Haltiwanger, Lane and Spletzer (1999), and Haskel, Hawkes and Periera (2005) find that the most productive firms have more skilled workers (in France, the US and UK, respectively).
\end{abstract}

Abstract

In this paper we utilise a specially-designed survey, the Business Strategy and Skills (BSS) module of the Business Operations Survey 2008 (BOS 2008) to investigate the determinants and intensity of training in three aspects: training of new staff; training of existing staff changing roles and the training of existing staff for their existing roles. We examine both the probability and intensity of each type of training as a function of the external and internal skill gaps as well as a suite of other variables including the firms' size, previous performance, its ownership, its

An important aspect of the relationship between skills and productivity is that the upgrading of skills is a continuous process (Gibson \& Watane, 2001). Education and training in the workplace play an important role in augmenting and adapting the skills of workers, particularly senior employees, whose skills accumulated at school are likely to be substantially depreciated, and for the less educated, who run the risk of social exclusion (Bassanini et. al,. 2005).

Information on why New Zealand employers do not train or train very few of their existing staff remains unclear and critical for policy-makers to design appropriate incentives to encourage firms to provide in-house training to their employees. The objective of this paper is to fill in some of this gap. We utilise a specially-designed survey, the Business Strategy and Skills (BSS) module of the Business Operations Survey 2008 (BOS 2008) to investigate the determinants and intensity of training in New Zealand firms. The data allow us to distinguish between three aspects of training in firms: training of new staff; training of existing staff changing roles and the training of existing staff for their existing roles, and the type of training employees participate in.

In the short run, shortages of appropriately-skilled workers can curtail economic activity (Stevens, 2007), but may also have longer-term impacts on the way firms do business, in terms of their location, size, structure, production methods and product strategy (Mason et. al., 2003; Durbin, 2004; Mason, 2005).

As well as benefits to the firm, individuals who participate in employment related training get improved occupational status, increased earnings potential, and a lower risk of unemployment (Blundell et al., 1999). These advantages are likely to have been amplified by changes in the New Zealand labour market and industrial relations framework in the last decade, with an increase in skills-based pay (Ryan, 1996).

In this paper we examine the probability and intensity of training as a function of the external skill gaps as well as a suite of other variables including the firms' size, previous performance, its ownership, its competitive environment and the occupational breakdown of its staff. 
This paper is organised as follows. The next section describes the data and the main descriptive statistics on training. The descriptive statistics is based on the tables obtained from the Statistics New Zealand, derived from the Business Operations Survey (BOS) 2008. Section 3 contains the description of the variables and models used in our analyses. Section 4 presents the empirical findings of our analyses. Section 5 presents our conclusions and suggestions for future research.

\section{Data}

\section{Business Operations Survey (BOS)}

Our data are drawn from the merging of three distinct sources. The main source of data is a specially-designed survey, the Business Strategy and Skills (BSS) module of the Business Operations Survey 2008 (BOS 2008). By combining the BSS module with data from other sections of the current and previous years' BOS and the prototype Longitudinal Business Database (LBD) we expand the analysis in two ways. First, we draw on additional explanatory variables from a wide range of sources (other surveys and administrative data). Second, we can exploit the panel nature of the dataset to consider issues of endogeneity in a more sophisticated manner.

The BOS is a modular business survey with three modules: Module A collects annual financial and employment data and qualitative information on firm performance; Module B alternates between collecting information on innovation and communication technology use; while Module $\mathrm{C}$ is a contracted module. In 2008, Module $\mathrm{C}$ was focused on the nature of establishments' current and future strategies, their market focus, skills requirements, internal and external skill gaps and training strategies. The target population for the BOS 2008 was active enterprise on Statistics New Zealand's (SNZ) Business Frame that at the population selection date: have an annual GST turnover figure of greater than \$30,000; had at least 6 employees; and had been operating for at least a year. It is a nationally representative survey of 36,075 New Zealand establishments for all sectors except for the government, private non-profit organisations serving households and households. BOS 2008 has two-levels of stratification according to ANZSIC industry and employment size groups. The survey's response rate is 81.8 percent, which represented 5,543 establishments in 2008 .

We then merged the BOS 2008 dataset with other databases namely the Linked Employer-Employee Database (LEED) and Business Activity Indicator (BAI) to obtain measures of the number of employees, labour productivity and relative wages for each firm. LEED contains the primary source of employment and is constructed by Statistics NZ from Inland Revenue Department (IRD) tax data, notably Pay-As-You-Earn returns for employees. BAI dataset consists of GST, sales and purchases and is collected on a monthly, bi-monthly or six-monthly basis by IRD, depending on the firm size. Upon merging the datasets, we obtain a final sample of 5,472 establishments with more than 6 employees and that are active over the period of 2008. We also include the BOS 2007 to consider the lagged effect of the establishments' previous strategies on the subsequent year's training propensity and intensity.

\section{Descriptive statistics from the BOS}

In this section, we present the main findings from the BOS 2008 on the proportion and intensity of training within firms based on the tables produced by Statistics New Zealand. Table 1 shows the percentage of establishment that provided training by firm size and industry. Over 80 percent of firms provided training in the last two years. The percentage of business that trains their staff increases with firm size, suggesting that larger firms are more likely to train their employees. The health care and social assistance, and education and training sectors have the largest percentage of firms that train their staff, while the agriculture, forestry and fishing and rental, hiring and real estate service sectors have the lowest.

As for the intensity of training, we focus on the proportion of staff participating in training for three staff types. Table 2 shows that over 50 percent of establishments trained all new staff, while 26 percent of firms trained all their existing staff (in their existing roles) and 24 percent business trained all staff that changed roles. Further inspection of the major sectors where all the staff participated in trainings from Table 2 reveals an interesting finding. Staff training in the health care and social assistance sector has the most extensive, with the majority of firms training all their new staff and existing staff for their existing roles. Training all existing staff that changes roles is not particularly high across industries, except for the financial and insurance services (38 percent). This might reflect a change in business strategy due to the worldwide financial crisis in 2008. As expected, large firms train a higher fraction of their staff compared to small and medium firms.

Table 3 further explains the types of training that employees participated in. Trade-related skills were ranked first, while computer skills and customer service skills ranked second and third, respectively. On the other hand, written communication skills and numeracy skills ranked last, which suggests that these skills are less important to the establishments. One might expect that these trainings vary depending on the types of establishments. Table 4 shows that staff in the construction sector receives the most training for traderelated skills while majority of the professional, scientific and technical services provide trainings in computer skills. Staff in the education and training sector receives the most training in written communication skills 
although it may not be the most important training in the sector.

\section{Econometric model}

\section{Incidence of Training}

The main objective of this paper is to analyse the circumstances under which the training within firms takes place. We use a probit regression model to estimate the probability of the incidence of training (at least one employee received a planned period of training during the last financial year) while controlling for other factors that may explain differences in the incidence of training across firms. The advantage of the model is that the independent effects of a set of variables can be analysed holding the effects of other hypothesised correlates constant (Tan et al., 2007). The model is estimated using the establishment-based weights to provide results that are representative of all New Zealand businesses.

Consider the following model:

$T_{s i}^{*}=\beta_{s i} X_{i}+\mu_{s i}$

$T_{s i}=1$ if $T_{s i}^{*}>0 ; T_{s i}=0$ otherwise

$T_{s i}^{*}$ is the unobserved net benefit (latent variable) to the employer providing training s. The establishment offers training $\left(T_{s i}=1\right)$ if the benefit of training is positive $\left(T_{s i}^{*}>0\right)$, if the benefit of training is not positive, the establishments will not support training. A set of $X$ variables represent the independent variables and both dichotomous and continuous variables. As independent variables, we identify two sets of regressors: controls and explanatory variables of organisational change that underlie the training decision of firms, as suggested by the economic literature. We include industry dummies to control for differences in the incidence in training across industries (e.g. some industries may have a history of training through the use of apprenticeship schemes). Firms are grouped into 23 industry categories using the ANZSIC96 classification system at the two digit level.

\section{Independent variables}

Training is seen as an investment decision in the human capital theory (Becker, 1964). This theory provides guidance in our selection of the independent variables. We grouped the variables into four major categories: business strategies; structural; employee characteristics; and skill gaps. Appendix 1 explains the independent variables in detail.

a) Business strategies
Business strategies include the innovation and technology change within establishments, new investment, research and development $(\mathrm{R} \& \mathrm{D})$, exporting firms, foreign-direct investment (FDI), overseas-direct investment (ODI) and the nature of the establishments' competition and market.

When a firm decides to innovate and or use the new technology in their production, the firm is faced with two options: to train their existing employees or hire new employees with the necessary skills. However, if the necessary knowledge is very specific or change is occurring frequently and quickly, it would be more efficient to train existing employees (Turcotte et al., 2002). Recruitment is particularly attractive when an establishment needs to acquire new capabilities.

Similarly, establishments that engage in R\&D, new investment and export are more likely to train their employees. Establishments that export have greater incentives to train their employees to produce high quality goods and services to meet the standards of foreign buyers and to increase labour productivity to meet competitive pressures (Batra \& Stone, 2004; Tan \& Batra, 1995). We also included the establishment's participation in international market sales to capture the effect of the international market on training. Thus, we would expect a positive relationship between training and innovation and technology, R\&D, new investment, exporting firms and exposure to international markets.

We have also included in the model a variable to capture whether an establishment is foreign-owned, which is thought might influence the propensity to train. Foreignowned establishments might be more likely to train the local employees to increase its labour productivity in order to meet competitive exporting pressures. We also tested whether local establishments that hold ownership in foreign establishments are more likely to train their employees.

We included several dichotomous variables to capture the source of competition to measure the impact of competition on whether an establishment provides training. The nature of competition on the establishment does not provide unambiguous a priori expectations because establishments which are engaged in a highly competitive market are more likely to train their employees to increase their productivity.

\section{b) Structural}

The structural variables include the size, industry, sales growth and unionisation of the establishments.

One would expect that larger firms are more likely to train due to economies of scale (Barron et al., 1987), better access to capital at beneficial rates (Hashimoto, 1979) and a greater capacity to absorb the costs associated with the turnover of trained workers 
(Holtmann \& Idson, 1991). Hence, we adopted the logarithm of the number of employees to capture this effect.

Establishments that have high sales growth have a higher propensity to train their employees due to the greater capacity to absorb the costs of training and to increase the labour productivity in order to retain the market share. Past literature suggested that trade union membership increases the likelihood of receiving training, since trade unions provide a collective voice in demanding training for the workers (Booth, 1991; Green, 1995). We adopted the findings from Acemoglu and Pischke (1999) which proved that unionisation will reduce the distribution of wages which might encourage establishments to fund general training due to the increased cost for employees to move to other firms.

\section{c) Employee characteristics}

We used a number of variables to capture differences between employees across establishments. These include the percentage of employees in each profession, worker turnover, wages relative to the mean 4-digit industry and labour productivity. Even though we are able to control for some worker characteristics within firms it is still possible that the results could be biased by the omission of other worker characteristics (Barnes and Dixon, 2010). While this concern cannot be discounted, a study by Frazis et al. (2000), using matched employeremployee data found that the relationship between establishment characteristics and training were not significantly altered by the inclusion of worker characteristics.

We introduced two new variables; new hires (nh) and net employment growth (neg) to capture the effect of employee turnover on training. Net employment growth is measured by the difference between accessions and separation of an average employee, and new hires could be viewed as new recruitment (measured by the accession per employee). They are substituted into the model to test the effects separately. We considered the average employee relative wage to account for wage disparities from differences in tenure, level of education and the profitability of the firm between and within industries. The relative wage is expected to have positive effect on the likelihood of training.

Previous studies suggest positive relationship between training and productivity (Batra \& Stone, 2004; Pells et al., 2004; Tan \& Batra, 1995). Thus, we included a measure of labour productivity in the model. Arguably, the lagged effects of the establishments' previous business strategies could have an impact on the current year's training provision. For this reason, we have included the previous year's innovation and technology adoption, relative wages, sales and export strategies into separate models.
We used a number of variables related to the skill gaps of employees employed by the establishments. These include the percentage of the vacancies in each profession (vacancies over total employment in each profession) and hard-to-fill (HTF) vacancies faced by the establishments. Turcotte et al. (2002) highlighted that the vacant positions could have resulted from frictional or organisational factors. Vacant positions could be the result of the skills of existing employees not matching those required by employers, which may mean establishments are more likely to invest in their existing employees. Alternatively, vacant positions could be as a result of the problems in retaining or recruiting employees. Hence, establishments may support training to attract potential employees and to improve retention of their existing employees. We have also included the HTF vacancies by occupation for the current and previous year to capture the lagged effects of these vacancies within the establishments on their propensity to train.

\section{Intensity of training}

After focussing on the probability of an establishment providing training, we next analyse training intensity (percentage of staff trained). BOS 2008 has provided unique information on the proportion of training for three types of employees: new staff; existing staff changing roles; and existing staff for their existing roles. Questions were asked whether the establishments provide training "less than half", "half or more", "all" or "no staff of this type" for all three types of employees. Training intensity is a latent variable which is not directly observable. We only observe the responses to the questions above on training intensity. We utilised the information to classify the training intensity into three separate models for each employee type using an ordered probit regression model. The training intensity for establishment $\left(T_{i}^{*}\right)$ is assumed to be determined by a set of independent variables $\left(X_{i}\right)$ which comprised of employees and establishments' characteristics. Consider the model below:

$T_{i}^{*}=\beta_{i} X_{i}+\mu_{i}$

The observed training intensity variable is assumed to be related to the latent training intensity in the following way:

$T_{i}=j$ if $\alpha_{j-1}<T_{i}^{*} \leq \alpha_{j}, j=0, \ldots, J$

where $j$ is the number of response categories; $\alpha_{j}$ are threshold levels that are empirically estimated. If training intensity $\left(T_{i}^{*}\right)$ is between $\alpha_{j-1}$ and $\alpha_{j}$, the response to the question on training intensity taken is equal to $j\left(T_{i}=j\right)$. 
We measured training intensity for all three types of employees by assigning a value of 0 to establishments that report no training and not having staff of this type; 1 for training less than half; 2 for training half or more; 3 for training all their staff. A training intensity of 2 indicates that more staff participated in training than a training indicator of 1 . Note that we applied almost the same independent variables as the probability to train models for the intensity of training models; which included the lagged effects.

\section{Empirical Results}

\section{Incidence of training}

The regression results, reported in Table 5, confirm the importance of several factors that influence the demand for training provision. We limit the discussion of the results to the variables with statistically significant coefficients. The first and second columns represent the contemporaneous models using BOS 2008, whereas the third and fourth columns incorporated the lagged effects. Model 1 and 3 experimented with labour turnover using net employment growth while Model 2 and 4 applied the new hires variables into both the contemporaneous and lagged models, respectively.

The results suggest that some business strategy variables are associated with firms' propensity to train staff. Interestingly, the establishments' new investment, new innovation and engagement in exporting activities do not seem to be related to training propensity. Instead, current new technology investment and R\&D strategies reveal a strong positive relationship with training propensity. The number of competitors in the market does not appear to have a significant effect on the probability to train. Establishments that hold ownership in foreign establishment (odi) seem more likely to train their employees.

The results showed some significant variables in the structural aspect of the establishments. Training is significantly higher among firms that are larger, which corroborates the conclusion from Table 1 and previous studies. Unionisation is also significant (at $10 \%$ significance level) for all the tested models, which suggests that the firm size and unionisation findings are robust. Interestingly, unionisation displays a negative relationship with training. This could be explained by assuming that the base salary of a unionised employee might be too high for the establishment to offer training for which it would have to pay in full since it would be unable to ask the worker to contribute towards the cost through a lower salary.

Employee characteristics appear to be associated with the firm's propensity to train. Establishments that reported having HTF vacancies, high worker turnover and employ a relatively high percentage of managers are more likely to train their employees. For the first 2 models, we tested different measurements of worker turnover separately and found only the net employment growth variable to be significant in the first model..

The likelihood of training increases with the percentage of managers employed, but decreases with other occupation groups. The former coefficients are significant for all four tested models. This suggests that a high percentage of employees in management positions is related to an establishment's decision to participate in training. However, the percentage of professionals and technicians do not appear to have a significant impact on the incidence of training for all models. This might suggest that training is only effective in the incremental development of skills. It could be the case that it is easier to augment the skill sets of managers, whereas for professionals with specialist skills it might be more cost effective to hire them instead.

Taking the lagged effects into consideration paints a slightly different picture on the propensity to train. Interestingly, establishments that report having HTF vacancies for tradespersons in the previous year are less likely to train their employees shown in Column 3 and 4. Establishments that are engaged in exporting activities in the previous year are more likely to train their employees in the current year.

\section{Intensity of training}

Table 6 shows the results of the ordered probit analyses of training intensity for all three types of staff, using contemporaneous and lagged models. Current investments and new technology of the establishments in Model 1, 3 and 5 of Table 6 show a significant and positive effect of increasing the odds of training more of its staff. This suggests that investment and technology are associated with increased training intensity for all three types of staff. Except for new staff, previous year's technology improvements and HTF vacancies have a positive impact on training existing staff. However, an establishment's previous year investments do not significantly influence the training intensity. Refer to Model 2, 4 and 6 in Table 6.

For new staff, both contemporaneous and lagged models showed a significant and positive relationship between training intensity and net employment growth. This is expected as more new staff are employed, more training will be conducted. Establishments that undertake innovation in both current and previous years have a significant and positive impact on the training intensity of new staff.

Interestingly, the current odi variable is positively significant for existing staff changing roles in Model 3, which suggest that when local establishments invest in an overseas firm they will train more of their existing 
staff that change roles, which might be because of an increase in their job functions. A high percentage of professionals employed within an establishment reduces the odds of training existing staff changing roles. This is significant for both contemporaneous and lagged models.

For the existing staff who remain in their existing roles, unionisation, HTF vacancies and technology improvement are significant determinants of the training intensity for both tested models. This corroborates with the results of the probit regression in Table 5, where unionisation reduces the odds of training more of the staff of this kind. 


\section{Discussion}

An establishment's business strategies, structure and employee characteristics appear to be related to an increased probability of training their staff. Establishments with more employees, undertake R\&D, have Hard-To-Fill vacancies and a relatively high percentage of managers are more likely to train their staff. The results also revealed a puzzling negative relationship between unionisation and the incidence of training in New Zealand firms. It would be interesting to investigate this further as other studies have found that unionised workplaces are associated with higher levels of training.

When looking at training intensity, we find that depending on the types of staff, some variables are significant while some are not. Business strategies such as new technology and new investment seem to have strong influence on training intensity. This is also true for the models using the lagged variables.

Our research aimed to identify which firm characteristics and behaviours are important in explaining individual heterogeneity in training propensity and intensity among firms. Further work is needed to better understand what types of staff firms decide to train and why.

\section{Notes}

1. The opinions, findings, recommendations and conclusions expressed in this paper are those of the author(s). Statistics NZ, MED, NIERS, and DoL take no responsibility for any omissions or errors in the information contained here. Access to the data used in this study was provided by Statistics NZ in accordance with security and confidentiality provisions of the Statistics Act 1975. Only people authorised by the Statistics Act 1975 are allowed to see data about a particular, business or organisation. The results in this paper have been confidentialised to protect individual businesses from identification. The results are based in part on tax data supplied by Inland Revenue to Statistics NZ under the Tax Administration Act 1994. This tax data must be used only for statistical purposes, and no individual information is published or disclosed in any other form, or provided back to Inland Revenue for administrative or regulatory purposes. Any person who had access to the unit-record data has certified that they have been shown, have read and have understood section 81 of the Tax Administration Act 1994, which relates to private and confidentiality. Any discussion of data limitations or weaknesses is not related to the data's ability to support Inland Revenue's core operational requirements. Any table or other material in this report may be reproduced and published without further licence, provided that it does not purport to be published under government authority and that acknowledgement is made of this source.

\section{References}

Abowd, K. \& Margolis. (1999). High Wage Workers and High Wage Firms. Econometrica, 67( 2 ), 251-333

Acemoglu, D. \& Pischke, J.F. (1998). Why Do Firms Train? Theory and Evidence. The Quarterly Journal of Economics.

Acemoglu, D. \& Pischke, J.F. (1999). The Structure of Wages and Investment in General Training. Journal of Political Economy, 107(3), 539-72.

Archer, S. (2007). The International Literature on Skills Training and the Scope for South African Application. Development Policy Research Unit Working Paper 07/142.

Antonelli, G., Antonietti, R. \& Guidetti, G. (2010). Organisational Change, Skills Formation, Human Capital Measurement: Evidence from Italian Manufacturing Firms. Journal of Economic Surveys, 24(2), 206-247.

Barron, J.M., Black, D.A. \& Loewenstein, M.A. (1989). Job Matching and On-the-job Training. Journal of Labor Economics, 7(1), 1-19.

Bassanini, A., Booth, A., Brunello, G., De Paola, M. \& Leuven, E. (2005). Workplace Training in Europe, IZA Discussion Papers 1640, Institute for the Study of Labor (IZA).

Batra, G. \& Stone, A. (2004). Investment Climate, Capabilities and Firm Performance: Evidence from the World Business Environment Surveys. Washington: World Bank Investment Climate Department.

Becker, G. (1964). Human Capital: A Theoretical and Empirical Analysis, With Special Reference to Education, Chicago: University of Chicago Press.

Blundell, R., Dearden, L., Meghir, C. \& Sianesi, B. (1999). Human capital investment: the returns from education and training to the individual, the firm and the economy. Fiscal Studies, 20(1), 1-23.

Department of Labour (forthcoming). Employerfunded Study and Training. Wellington: Department of Labour.

Durbin (2004). Workplace skills, technology adoption and firm productivity: A review. New Zealand Treasury working paper 04/16. 
Forth, J., Mason, G. \& O'Mahony, M. (2002). Industrial Performance, ICT Investments and Workforce Skills: Literature and Statistical Review. Department for Education and Skills, London.

Frazis, H., Gittleman, M. \& Joyce, M. (2000). Correlates of Training: An Analysis Using Both Employer and Employee Characteristics. Industrial and Labour Relations Review, 53(3), 443-62.

Gibson, J. \& Watane, C. (2001). Why Is Job Security Lower for Maori and Pacific Island Workers? The Role of Employer-Provided Training. New Zealand Economic Papers, 35.

Haltiwanger, J.C., Lane, J. \& Spletzer, J. (1999). Productivity Differences across Employers: The Roles of Employer Size, Age, and Human Capital. American Economic Review, 89(2), 94-98.

Hashimoto, M. (1979). Bonus Payments, On-the-job Training and Life-time Employment in Japan. Journal of Political Economy, 1086-1104.

Haskel, J., Hawkes, D. \& Pereira, S. (2005). Skills, human capital and the plant productivity gap: UK evidence from matched plant, worker and workforce data. CEPR Discussion Papers 5334, C.E.P.R. Discussion Papers.

Holtmann, A.G. \& Idson, T.L. (1991). Employer Size and On-the-job Training Decision. Southern Economic Journal, 58(2), 33-55.

Mason, G., Forth, J., Stevens, P., Wilson, R., Campbell, D., Dickerson, A. \& Hogarth, T. (2003). Employers Skills Surveys: New Analyses and Lessons Learned. Report NALL1. Department for Education and Skills, London.

Mason, G. (2005). In Search of High Value Added Production: How Important are Skills? Investigations in the Plastics Processing Printing, Logistics and Insurance Industries in the UK. Research Report RR663, Department of Education and Skills, London.

Pells, S., Steel, D. \& Cox, M. (2004). Industry Training and Productivity - A literature review. NZIER Report to the Industry Training Federation.

Ryan, R. (1996). Should New Zealand have a WIRS? Labour Market Bulletin 1996:1, 101-111.

Statistics New Zealand (2009). Business Operations Survey: 2008 Tables. Available at http://stats.govt.nz/methods_and_services/accessdata/tables/business-opsurvey-2008.aspx
Stevens, A. (2007). Skill shortages and firms' employment behaviour. Labour Economics, 14(2), 231-249.

Shields, M. (1998). Changes in the Determinants of Employer-funded Training for Full-time Employees in Britain, 1984-1994. Oxford Bulletin of Economics and Statistics, 60(2), 189-212.

Tan, H. \& Batra, G. (1995). Enterprise Training in Developing Countries: Incidence, Productivity Effects, and Policy Implications. Washington: World Bank PSD Department Monograph.

Tan, H., Savchenko, Y., Gimpelson, V., Kapelyushnikov, R. Lukyanova, A. (2007). Skills Shortages and Training in Russian Enterprises. Washington: World Bank Policy Research Working Paper 4222.

Turcotte, J., Leonard, A. \& Montmarquette, C. (2002). New Evidence on the Determinants of Training in Canadian Business Locations. Applied Research Branch, Strategic Policy, Human Resources Development Canada. Canada: Working Paper W029E. 
Table 1: Percentage of Establishments that Trained staff in the Last Two Years by Firm size and Industry (at Aug 2008)

\section{Percent (\%)}

\section{Business size}

6-19 employees

20-49 employees

50-99 employees

$100+$ employees

\section{Industry}

Agriculture, forestry and fishing

Rental, hiring and real estate services

Arts and recreation services

Manufacturing

Wholesale trade

Accommodation and food services

Transport, postal and warehousing

Other services

Information media and telecommunications

Administrative and support services

Mining

Electricity, gas, water and waste services

Retail trade

Construction

Financial and insurance services

$\begin{array}{lr}\text { Professional, scientific and technical services } & 90\end{array}$

Education and training $\quad 92$

Health care and social assistance $\quad 94$

Source: BOS 2008, Statistics New Zealand. 


\begin{tabular}{|c|c|c|c|c|c|c|c|c|c|}
\hline & \multicolumn{9}{|c|}{ Percentage participating in training } \\
\hline & \multicolumn{2}{|c|}{ New Staff } & & \multicolumn{3}{|c|}{$\begin{array}{l}\text { Existing staff } \\
\text { changing roles }\end{array}$} & \multicolumn{3}{|c|}{$\begin{array}{l}\text { Existing staff for } \\
\text { existing roles }\end{array}$} \\
\hline & $\begin{array}{l}\text { Less } \\
\text { than } \\
\text { half }\end{array}$ & $\begin{array}{l}\text { Half } \\
\text { or } \\
\text { more }\end{array}$ & All & $\begin{array}{l}\text { Less } \\
\text { than } \\
\text { half }\end{array}$ & $\begin{array}{l}\text { Half } \\
\text { or } \\
\text { more }\end{array}$ & All & $\begin{array}{l}\text { Less } \\
\text { than } \\
\text { half }\end{array}$ & $\begin{array}{l}\text { Half } \\
\text { or } \\
\text { more }\end{array}$ & All \\
\hline \multicolumn{10}{|l|}{ Business size } \\
\hline 6-19 employees & 8 & 11 & 48 & 12 & 10 & 21 & 23 & 22 & 28 \\
\hline 20-49 employees & 10 & 11 & 61 & 18 & 16 & 30 & 33 & 25 & 26 \\
\hline 50-99 employees & 11 & 17 & 65 & 21 & 24 & 37 & 41 & 32 & 19 \\
\hline 100+ employees & 9 & 19 & 68 & 19 & 35 & 36 & 41 & 39 & 15 \\
\hline \multicolumn{10}{|l|}{ Industry } \\
\hline Agriculture, forestry and fishing & 8 & 15 & 41 & 12 & 12 & 18 & 23 & 16 & 23 \\
\hline Mining & 11 & 6 & 63 & 14 & 17 & 31 & 26 & 29 & 26 \\
\hline Manufacturing & 13 & 9 & 47 & 19 & 14 & 20 & 38 & 16 & 16 \\
\hline Electricity, gas, water and waste services & 14 & 11 & 57 & 20 & 14 & 31 & 40 & 23 & 20 \\
\hline Construction & 11 & 13 & 51 & 15 & 21 & 9 & 34 & 30 & 21 \\
\hline Wholesale trade & 11 & 12 & 47 & 16 & 12 & 23 & 37 & 20 & 19 \\
\hline Retail trade & 3 & 14 & 61 & 12 & 14 & 31 & 21 & 28 & 30 \\
\hline Accommodation and food services & 11 & 10 & 56 & 13 & 8 & 32 & 19 & 22 & 29 \\
\hline Transport, postal and warehousing & 4 & 6 & 60 & 12 & 12 & 24 & 23 & 16 & 32 \\
\hline Information media and telecommunications & 13 & 11 & 48 & 18 & 17 & 22 & 35 & 26 & 15 \\
\hline Financial and insurance services & 8 & 5 & 57 & 13 & 12 & 38 & 24 & 27 & 35 \\
\hline Rental, hiring and real estate services & 2 & 12 & 49 & 5 & 18 & 21 & 21 & 22 & 25 \\
\hline Professional, scientific and technical services & 7 & 14 & 51 & 7 & 9 & 28 & 23 & 25 & 39 \\
\hline Administrative and support services & 6 & 10 & 63 & 14 & 17 & 30 & 22 & 28 & 25 \\
\hline Education and training & 9 & 14 & 61 & 16 & 12 & 34 & 18 & 35 & 36 \\
\hline Health care and social assistance & 3 & 10 & 66 & 10 & 13 & 30 & 12 & 35 & 44 \\
\hline Arts and recreation services & 4 & 8 & 55 & 12 & 7 & 34 & 20 & 19 & 32 \\
\hline Other services & 16 & 18 & 23 & 13 & 6 & 11 & 24 & 30 & 22 \\
\hline Overall & 8 & 12 & 52 & 13 & 13 & 24 & 26 & 24 & 26 \\
\hline
\end{tabular}


Table 3: Percentage of Training Staff Participated by Training Type in the Last Two Years

\begin{tabular}{llll}
\hline & \multicolumn{3}{l}{ Percentage of staff participation in trainings provided by firms } \\
\cline { 2 - 4 } Training type & Yes & Ranked & Skills not required \\
\hline Trade related skills & 43 & 1 & 19 \\
Computer skills & 36 & 2 & 15 \\
Customer service / sales skills & 35 & 3 & 16 \\
Team working skills & 32 & 4 & 9 \\
Professional / technical skills & 32 & 5 & 22 \\
Management / supervisory skills & 28 & 6 & 16 \\
Oral communication & 17 & 7 & 11 \\
Marketing skills & 15 & 8 & 26 \\
Written communication skills & 13 & 9 & 14 \\
Numeracy skills & 12 & 10 & 14 \\
\hline
\end{tabular}

Source: BOS 2008, Statistics New Zealand. 


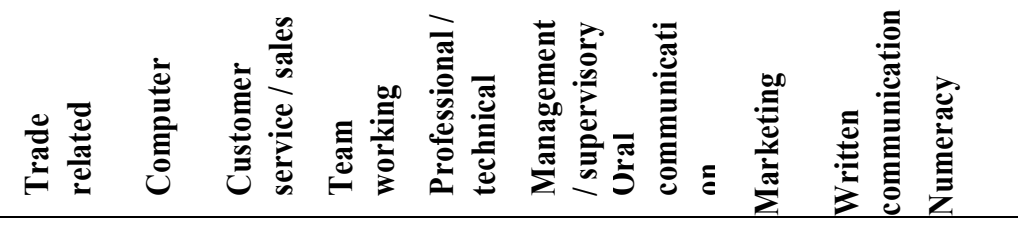

\begin{tabular}{|c|c|c|c|c|c|c|c|c|c|c|}
\hline \multicolumn{11}{|l|}{ Industry } \\
\hline Agriculture, forestry and fishing & 45 & 16 & 5 & 23 & 16 & 20 & 9 & 5 & 7 & 7 \\
\hline Mining & 57 & 34 & 11 & 34 & 51 & 40 & 11 & 11 & 14 & 20 \\
\hline Manufacturing & 52 & 36 & 23 & 24 & 25 & 26 & 13 & 13 & 12 & 12 \\
\hline Electricity, gas, water and waste services & 31 & 34 & 31 & 29 & 26 & 31 & 17 & 14 & 11 & 14 \\
\hline Construction & 74 & 27 & 8 & 31 & 17 & 13 & 10 & 6 & 9 & 9 \\
\hline Wholesale trade & 29 & 52 & 48 & 24 & 39 & 26 & 17 & 22 & 10 & 10 \\
\hline Retail trade & 46 & 36 & 69 & 38 & 18 & 37 & 24 & 26 & 12 & 16 \\
\hline Accommodation and food services & 33 & 20 & 55 & 40 & 10 & 22 & 24 & 13 & 13 & 16 \\
\hline Transport, postal and warehousing & 26 & 31 & 29 & 23 & 21 & 28 & 13 & 9 & 13 & 11 \\
\hline Information media and telecommunications & 26 & 47 & 44 & 30 & 40 & 26 & 18 & 25 & 12 & 11 \\
\hline Financial and insurance services & 23 & 52 & 57 & 39 & 69 & 46 & 24 & 33 & 20 & 13 \\
\hline Rental, hiring and real estate services & 18 & 46 & 46 & 28 & 29 & 31 & 21 & 24 & 16 & 10 \\
\hline Professional, scientific and technical services & 20 & 63 & 26 & 34 & 80 & 38 & 16 & 17 & 20 & 15 \\
\hline Administrative and support services & 33 & 40 & 40 & 40 & 31 & 35 & 22 & 23 & 17 & 13 \\
\hline Education and training & 33 & 45 & 33 & 47 & 66 & 40 & 33 & 14 & 32 & 20 \\
\hline Health care and social assistance & 54 & 40 & 45 & 44 & 67 & 45 & 24 & 8 & 17 & 8 \\
\hline Arts and recreation services & 37 & 34 & 54 & 41 & 25 & 36 & 27 & 32 & 16 & 22 \\
\hline Other services & 69 & 24 & 19 & 17 & 41 & 24 & 12 & 14 & 7 & 6 \\
\hline Overall & 43 & 36 & 35 & 32 & 32 & 28 & 17 & 15 & 13 & 12 \\
\hline
\end{tabular}


Table 5: Probit regressions for Training propensity

\begin{tabular}{|c|c|c|c|c|}
\hline Variables & Model 1 & Model 2 & Model 3 & Model 4 \\
\hline \multirow[t]{2}{*}{ lnrw } & 0.058 & 0.074 & 0.064 & 0.050 \\
\hline & $(0.156)$ & $(0.154)$ & $(0.170)$ & $(0.171)$ \\
\hline \multirow[t]{2}{*}{ lnemp } & $0.323 *$ & 0.307 & $0.458^{* *}$ & $0.480 * *$ \\
\hline & $(0.195)$ & $(0.193)$ & $(0.205)$ & $(0.209)$ \\
\hline \multirow[t]{2}{*}{$\operatorname{lnLP}$} & -0.087 & -0.077 & -0.124 & -0.126 \\
\hline & $(0.097)$ & $(0.099)$ & $(0.111)$ & $(0.111)$ \\
\hline \multirow[t]{2}{*}{ neg } & $1.440 * *$ & & 0.555 & \\
\hline & $(0.622)$ & & $(0.684)$ & \\
\hline \multirow[t]{2}{*}{ Insales } & -0.003 & -0.008 & -0.000 & -0.007 \\
\hline & $(0.098)$ & $(0.097)$ & $(0.127)$ & $(0.127)$ \\
\hline \multirow[t]{2}{*}{ union } & $-0.238^{*}$ & $-0.242 *$ & $-0.297^{*}$ & $-0.299 *$ \\
\hline & $(0.142)$ & $(0.141)$ & $(0.169)$ & $(0.168)$ \\
\hline \multirow[t]{2}{*}{ mark_int } & -0.148 & -0.165 & -0.228 & -0.238 \\
\hline & $(0.229)$ & $(0.258)$ & $(0.334)$ & $(0.330)$ \\
\hline \multirow[t]{2}{*}{ odi } & $0.423 *$ & 0.398 & $0.541 *$ & $0.545^{*}$ \\
\hline & $(0.255)$ & $(0.249)$ & $(0.320)$ & $(0.321)$ \\
\hline \multirow[t]{2}{*}{ fdi } & 0.244 & 0.235 & 0.288 & 0.320 \\
\hline & $(0.362)$ & $(0.363)$ & $(0.450)$ & $(0.466)$ \\
\hline \multirow[t]{2}{*}{ comp1 } & 0.241 & 0.256 & -0.033 & -0.036 \\
\hline & $(0.254)$ & $(0.253)$ & $(0.267)$ & $(0.262)$ \\
\hline \multirow[t]{2}{*}{ comp2 } & -0.038 & -0.021 & 0.056 & 0.059 \\
\hline & $(0.174)$ & $(0.174)$ & $(0.199)$ & $(0.193)$ \\
\hline \multirow[t]{2}{*}{ comp3 } & 0.181 & 0.198 & 0.153 & 0.151 \\
\hline & $(0.160)$ & $(0.160)$ & (0.194) & $(0.194)$ \\
\hline \multirow[t]{2}{*}{ comp4 } & $-0.762 * * *$ & $-0.769 * * *$ & $-0.737 * *$ & $-0.741 * *$ \\
\hline & $(0.256)$ & $(0.262)$ & $(0.334)$ & $(0.337)$ \\
\hline \multirow[t]{2}{*}{ inv } & 0.172 & 0.185 & 0.081 & 0.078 \\
\hline & $(0.141)$ & $(0.140)$ & $(0.165)$ & $(0.164)$ \\
\hline \multirow[t]{2}{*}{ rnd } & $0.544 * * *$ & $0.536 * * *$ & $1.084 * * *$ & $1.061 * * *$ \\
\hline & $(0.208)$ & $(0.205)$ & $(0.330)$ & $(0.328)$ \\
\hline \multirow[t]{2}{*}{ HTF } & $0.366^{* * *}$ & $0.368 * * *$ & $0.611 * * *$ & $0.606^{* * *}$ \\
\hline & $(0.115)$ & $(0.115)$ & $(0.136)$ & $(0.136)$ \\
\hline \multirow[t]{2}{*}{ vacl } & -0.008 & -0.009 & -0.003 & -0.004 \\
\hline & $(0.014)$ & $(0.013)$ & $(0.017)$ & $(0.018)$ \\
\hline \multirow[t]{2}{*}{ vac2 } & 0.007 & 0.004 & 0.000 & 0.000 \\
\hline & $(0.010)$ & $(0.010)$ & $(0.000)$ & $(0.000)$ \\
\hline \multirow[t]{2}{*}{ vac4 } & 0.001 & 0.001 & 0.004 & 0.004 \\
\hline & $(0.001)$ & $(0.001)$ & $(0.006)$ & $(0.006)$ \\
\hline \multirow[t]{2}{*}{$\operatorname{vac} 5$} & 0.000 & 0.000 & 0.001 & 0.001 \\
\hline & $(0.001)$ & $(0.001)$ & $(0.001)$ & $(0.001)$ \\
\hline vac6 & -0.000 & -0.000 & -0.002 & -0.002 \\
\hline
\end{tabular}




\begin{tabular}{|c|c|c|c|c|}
\hline & $(0.000)$ & $(0.000)$ & $(0.001)$ & $(0.001)$ \\
\hline \multirow[t]{2}{*}{ prop_man } & $0.014 * *$ & $0.014 * *$ & $0.013^{*}$ & $0.012^{*}$ \\
\hline & $(0.006)$ & $(0.006)$ & $(0.007)$ & $(0.007)$ \\
\hline \multirow[t]{2}{*}{ prop_prof } & -0.002 & -0.002 & -0.000 & -0.000 \\
\hline & $(0.006)$ & $(0.006)$ & $(0.007)$ & $(0.007)$ \\
\hline \multirow[t]{2}{*}{ prop_tec } & -0.003 & -0.004 & -0.006 & -0.006 \\
\hline & $(0.005)$ & $(0.005)$ & $(0.006)$ & $(0.006)$ \\
\hline \multirow[t]{2}{*}{ prop_trade } & $-0.008^{* *}$ & $-0.008^{* *}$ & -0.004 & -0.004 \\
\hline & $(0.003)$ & $(0.003)$ & $(0.004)$ & $(0.004)$ \\
\hline \multirow[t]{2}{*}{ prop_lab } & $-0.005^{*}$ & $-0.005^{*}$ & -0.003 & -0.004 \\
\hline & $(0.003)$ & $(0.003)$ & $(0.004)$ & $(0.004)$ \\
\hline \multirow[t]{2}{*}{ ino } & 0.152 & 0.182 & 0.127 & 0.131 \\
\hline & $(0.134)$ & $(0.133)$ & $(0.178)$ & $(0.176)$ \\
\hline \multirow[t]{2}{*}{$\exp$} & 0.092 & 0.123 & $0.564^{*}$ & $0.554^{*}$ \\
\hline & $(0.238)$ & $(0.239)$ & $(0.330)$ & $(0.327)$ \\
\hline \multirow[t]{2}{*}{ tech } & $0.518^{* * *}$ & $0.511 * * *$ & 0.236 & 0.248 \\
\hline & $(0.132)$ & $(0.132)$ & $(0.178)$ & $(0.178)$ \\
\hline \multirow[t]{2}{*}{$\mathrm{nh}$} & & 0.154 & & 0.072 \\
\hline & & $(0.446)$ & & $(0.562)$ \\
\hline \multirow[t]{2}{*}{ HTF_manager } & & & 0.081 & 0.074 \\
\hline & & & $(0.193)$ & $(0.193)$ \\
\hline \multirow[t]{2}{*}{ HTF_tech } & & & -0.015 & -0.005 \\
\hline & & & $(0.170)$ & $(0.171)$ \\
\hline \multirow[t]{2}{*}{ HTF_trade } & & & $-0.290^{*}$ & $-0.281^{*}$ \\
\hline & & & $(0.169)$ & $(0.169)$ \\
\hline \multirow[t]{2}{*}{ HTF_other } & & & 0.151 & 0.147 \\
\hline & & & $(0.157)$ & $(0.162)$ \\
\hline \multirow[t]{2}{*}{ Constant } & 0.687 & 0.631 & 0.448 & 0.537 \\
\hline & $(1.204)$ & $(1.292)$ & $(1.505)$ & $(1.461)$ \\
\hline Industry dummies & Yes & Yes & Yes & Yes \\
\hline Observation & 3279 & 3279 & 2325 & 2325 \\
\hline F test & 2.836 & 2.862 & 3.092 & 3.113 \\
\hline Prob $>F$ & 0.000 & 0.000 & 0.000 & 0.000 \\
\hline
\end{tabular}

Notes: Standard errors in parentheses

* significant at $10 \% ;{ }^{* *}$ significant at $5 \% ; * * *$ significant at $1 \%$

Stratified and weighted. 
Table 6: Ordered probit training intensity (with lagged variables)

\begin{tabular}{|c|c|c|c|c|c|c|}
\hline Variable & $\begin{array}{l}\text { Model 1: } \\
\text { Newstaff }\end{array}$ & $\begin{array}{l}\text { Model 2: } \\
\text { Newstaff }^{1}\end{array}$ & $\begin{array}{l}\text { Model 3: } \\
\text { Change }\end{array}$ & $\begin{array}{l}\text { Model 4: } \\
\text { Change }^{1}\end{array}$ & $\begin{array}{l}\text { Model 5: } \\
\text { Exist }\end{array}$ & $\begin{array}{l}\text { Model 6: } \\
\text { Exist }^{1}\end{array}$ \\
\hline \multirow[t]{2}{*}{$\operatorname{lnrw}$} & 0.024 & -0.007 & 0.068 & $0.255^{* *}$ & -0.001 & 0.061 \\
\hline & $(0.111)$ & $(0.139)$ & $(0.117)$ & $(0.124)$ & $(0.125)$ & $(0.136)$ \\
\hline \multirow[t]{2}{*}{ lnemp } & 0.205 & 0.221 & $0.254^{*}$ & -0.018 & 0.009 & -0.062 \\
\hline & $(0.133)$ & $(0.171)$ & $(0.137)$ & $(0.160)$ & $(0.148)$ & $(0.164)$ \\
\hline \multirow[t]{2}{*}{$\operatorname{lnLP}$} & 0.047 & -0.040 & 0.001 & $-0.149 * *$ & -0.032 & -0.073 \\
\hline & $(0.060)$ & $(0.078)$ & $(0.066)$ & $(0.067)$ & $(0.057)$ & $(0.067)$ \\
\hline \multirow[t]{2}{*}{ neg } & $0.973^{* *}$ & $0.852 *$ & 0.557 & 0.112 & $0.916^{* *}$ & 0.334 \\
\hline & $(0.447)$ & $(0.501)$ & $(0.400)$ & $(0.541)$ & $(0.427)$ & $(0.454)$ \\
\hline \multirow[t]{2}{*}{ Insales } & -0.106 & -0.023 & -0.005 & 0.088 & 0.050 & 0.070 \\
\hline & $(0.067)$ & $(0.093)$ & $(0.080)$ & $(0.078)$ & $(0.078)$ & $(0.088)$ \\
\hline \multirow[t]{2}{*}{ union } & -0.130 & $-0.257 * *$ & 0.073 & -0.078 & $-0.221 * *$ & $-0.280 * * *$ \\
\hline & $(0.097)$ & $(0.115)$ & $(0.093)$ & $(0.107)$ & $(0.088)$ & $(0.108)$ \\
\hline \multirow[t]{2}{*}{ mark_int } & -0.030 & -0.031 & -0.232 & -0.077 & -0.013 & -0.064 \\
\hline & $(0.169)$ & $(0.220)$ & $(0.168)$ & $(0.200)$ & $(0.176)$ & $(0.215)$ \\
\hline \multirow[t]{2}{*}{ odi } & $0.208^{*}$ & 0.196 & $0.235^{* *}$ & 0.181 & -0.050 & -0.101 \\
\hline & $(0.124)$ & $(0.140)$ & $(0.118)$ & $(0.122)$ & $(0.100)$ & $(0.109)$ \\
\hline \multirow[t]{2}{*}{ fdi } & -0.082 & 0.100 & 0.066 & 0.104 & -0.109 & 0.083 \\
\hline & $(0.163)$ & $(0.154)$ & $(0.175)$ & $(0.155)$ & $(0.159)$ & $(0.154)$ \\
\hline \multirow[t]{2}{*}{ comp1 } & -0.001 & -0.065 & 0.279 & -0.031 & -0.013 & -0.064 \\
\hline & $(0.190)$ & $(0.235)$ & $(0.210)$ & $(0.267)$ & $(0.180)$ & $(0.223)$ \\
\hline \multirow[t]{2}{*}{ comp2 } & -0.127 & -0.111 & $0.217^{* *}$ & 0.162 & -0.135 & -0.123 \\
\hline & $(0.115)$ & $(0.147)$ & $(0.109)$ & $(0.138)$ & $(0.107)$ & $(0.131)$ \\
\hline \multirow[t]{2}{*}{ comp3 } & -0.100 & -0.056 & -0.009 & -0.023 & 0.091 & 0.025 \\
\hline & $(0.108)$ & $(0.129)$ & $(0.099)$ & $(0.120)$ & $(0.099)$ & $(0.120)$ \\
\hline \multirow[t]{2}{*}{ comp4 } & $-0.515^{* *}$ & -0.392 & 0.086 & -0.235 & -0.356 & -0.127 \\
\hline & $(0.214)$ & $(0.240)$ & $(0.205)$ & $(0.233)$ & $(0.222)$ & $(0.265)$ \\
\hline \multirow[t]{2}{*}{ inv } & $0.218^{* *}$ & 0.097 & $0.179 * *$ & -0.107 & $0.165^{*}$ & -0.059 \\
\hline & $(0.094)$ & $(0.121)$ & $(0.090)$ & $(0.107)$ & $(0.087)$ & $(0.103)$ \\
\hline \multirow[t]{2}{*}{ rnd } & 0.061 & -0.003 & -0.071 & 0.058 & 0.087 & 0.010 \\
\hline & $(0.136)$ & $(0.188)$ & $(0.116)$ & $(0.143)$ & $(0.104)$ & $(0.162)$ \\
\hline \multirow[t]{2}{*}{ HTF } & 0.113 & $0.308 * * *$ & $0.199 * *$ & $0.232 * *$ & $0.194 * *$ & $0.227 * *$ \\
\hline & $(0.086)$ & $(0.106)$ & $(0.080)$ & $(0.105)$ & $(0.081)$ & $(0.101)$ \\
\hline \multirow[t]{2}{*}{ vac1 } & -0.002 & 0.009 & 0.007 & $0.029^{*}$ & 0.000 & 0.010 \\
\hline & $(0.010)$ & $(0.013)$ & $(0.010)$ & $(0.016)$ & $(0.009)$ & $(0.013)$ \\
\hline \multirow[t]{2}{*}{$\operatorname{vac} 2$} & -0.000 & 0.000 & $0.016^{* *}$ & 0.013 & 0.000 & 0.000 \\
\hline & $(0.000)$ & $(0.000)$ & $(0.007)$ & $(0.010)$ & $(0.000)$ & $(0.000)$ \\
\hline \multirow[t]{2}{*}{ vac4 } & $0.000 * * *$ & 0.001 & $0.000 * * *$ & -0.004 & $0.000 * * *$ & -0.003 \\
\hline & $(0.000)$ & $(0.003)$ & $(0.000)$ & $(0.003)$ & $(0.000)$ & $(0.004)$ \\
\hline \multirow[t]{2}{*}{$\operatorname{vac} 5$} & 0.003 & 0.002 & -0.000 & $0.004 *$ & 0.002 & 0.002 \\
\hline & $(0.002)$ & $(0.002)$ & $(0.002)$ & $(0.002)$ & $(0.002)$ & $(0.002)$ \\
\hline \multirow[t]{2}{*}{ vac6 } & -0.001 & -0.002 & -0.000 & -0.000 & -0.001 & -0.001 \\
\hline & $(0.001)$ & $(0.001)$ & $(0.000)$ & $(0.000)$ & $(0.001)$ & $(0.001)$ \\
\hline
\end{tabular}




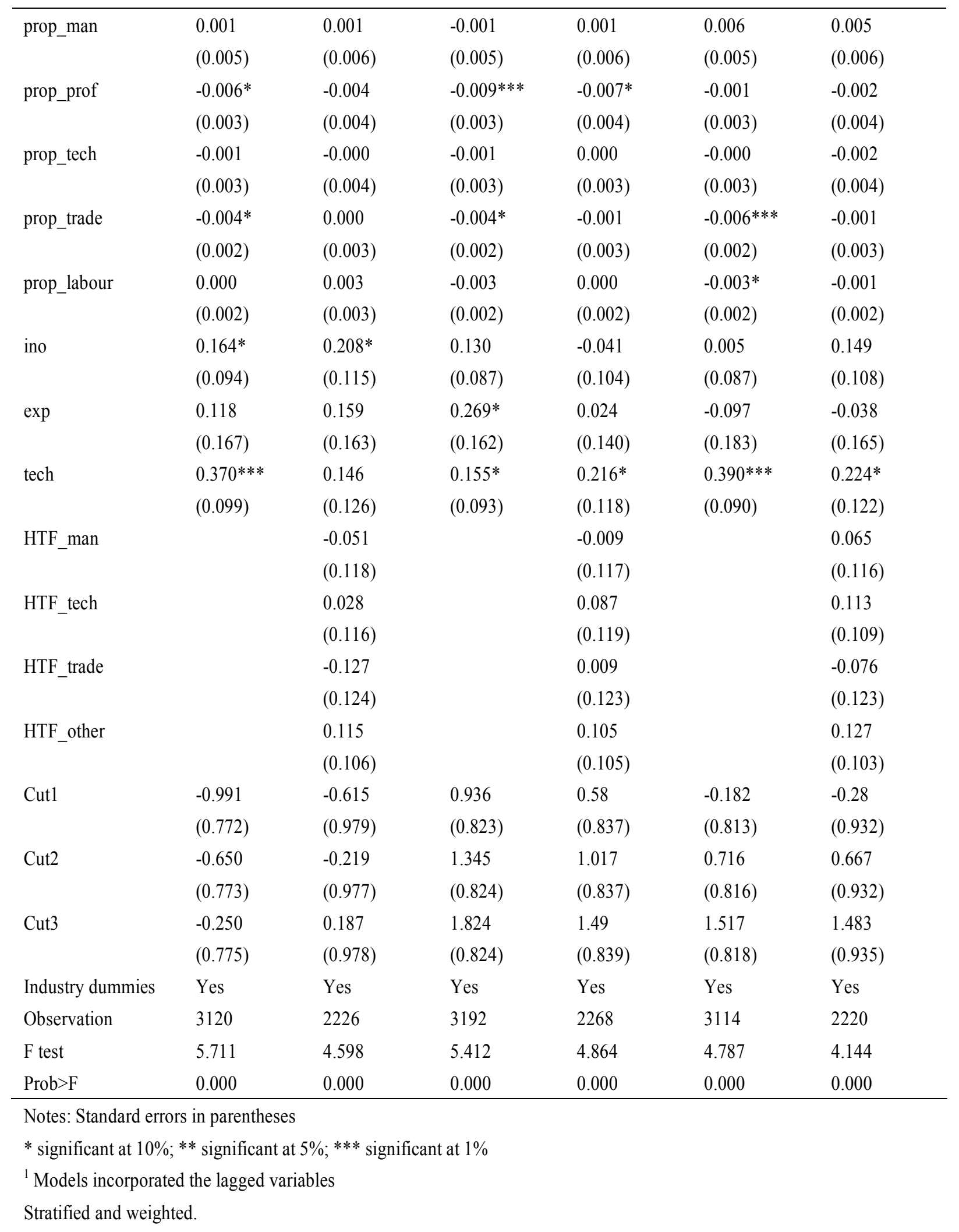

